\title{
The Chemical Quality of Maggot Flour Uses Sangrai Method Processing
}

\author{
Lestariningsih $^{(1)}$, Tika Fitria Wulan Afrilia ${ }^{(2)}$, Muhammad Muhsin ${ }^{(3)}$, Muhammad Yusuf Yasin ${ }^{(4)}$, \\ Mas'ud Zakqi Hupron ${ }^{(5)}$
}

Universitas Nahdlatul Ulama Blitar, Indonesia

E-mail: ${ }^{(1)}$ tariunu@gmail.com, ${ }^{(2)}$ tika.afrilia@gmail.com, ${ }^{(3)}$ muhammadmuhsin512@gmail.com, (4)escelop29@gmail.com, ${ }^{(5)}$ hupron151198@gmail.com

Received: 15 April 2020; Revised: 24 May 2021; Accepted: 29 May 2021

\begin{abstract}
The purpose of this study is to determine the differences of chemical quality of fresh maggot flour processed by using sangrai method. Currently maggot flour is popular among breeders because it contents high enough protein and has potential as a substitution of fish meal which has been imported at in very costly price. This research is conducted experimental methods on April 2021. The research consists of making maggot flour and continued to chemical analysis (proximate). Maggot which is processed into flour is obtained from maggot breeders in Blitar district. Maggot is processed by using sangrai method is carried out in Dayu Village, Nglegok District, Blitar Regency. Proximate analysis is carried out at the Nutrition and Animal Feed Laboratory of the Fisheries and Livestock Service Office of Blitar Regency. The sangrai method processing produces lower moisture content (5.69\%) so that it is predicted to have a better shelf life. The rough protein is $28.73 \%$, the rough fat content is $15.79 \%$, and the rough fiber content is $10.60 \%$. The results are considering higher. The maggot processed by using sangrai method can be applied, but it needs to be accompanied by further researches to reduce the higher rough fat and rough fiber content, one of them is fermentation.
\end{abstract}

Keywords: maggot; flour; proximate

\section{INTRODUCTION}

Animal feeding accounts for $70 \%$ of operational costs (Katayane et al., 2014). This has high impact on the feed prices which has been fluctuative. The formulation of animal feeding always considers the adequacy of the nutritional needs of livestock. One part of the nutritional content that is very concerned about is rough protein. Protein plays a role in the formation of livestock body tissue and it closely related to metabolism such as enzymes, hormones and antibodies (Beski et al., 2015). Protein sources are divided into vegetable and animal protein sources. So far, protein sources are still dependent on imports. This has an impact on the price of protein feed raw materials, which tends to be expensive compared to other nutritional sources (Wardhana, 2017). Fluctuating feed ingredients have an impact on high feed prices and affect farmers' income (Rambet et al., 2015).

There are many studies related to maggot which provide potential subtitution for a source of animal protein, namely fish meal (Rachmawati \& Samidjan, 2013). This is because maggot flour has a relatively low price and has relatively high rough protein content (Kardana et al., 2012). The maggot is the insect larvae of Hermetia illucens / Black Soldier Fly (BSF) which is often used as a bioconversion 
agent (Suciati et al., 2017). Maggots can grow and develop in media that are fulfilled with the nutritional needs of their life. The high and low protein content of maggot is influenced by its'growing medium and its' method processing (Aldi et al., 2018). In general, maggots contain protein at range of 30-45\% (Azir et al., 2017). Maggot flour contains of $32-58 \%$ rough protein, and 15 - 39\% rough fat content (Gold et al., 2018). In addition, other research states that the rough protein content of maggot flour is $41.76 \%$ (Gao et al., 2019).

The relatively high content of rough protein can potentially be used as a substitute for fish meal. Fish meal in poultry feeding formulation is never abandoned because it greatly impacts the performance of poultry production (Wardhana, 2017). From various research results on substitution of fish meal by using maggot flour, the variations of maggot contents are found. One of the factors that influence it is the method processing used for maggot siege. This processing faktor is very importand because it affects the nutritional content of feed ingredients and also operational cost in the field of animal husbandry, especially feed ingredients and also operational cost in field of animal husbandry, especially feed.

\section{MATERIALS AND METHODS Time and Research Place}

This research was conducted on April 2021. The research stages consist of making maggot flour and continued to chemical analysis (proximate). Maggot which is processed into flour is obtained from maggot breeders in Blitar district. Maggot processing uses sangrai method is done in Dayu Village, Nglegok District, Blitar Regency. Proximate analysis was carried out at the Nutrition and Animal Feed Laboratory of the Fisheries and Livestock Service Office of Blitar Regency.

\section{Research Methods}

This research is an empirical approach by applying experimental or experimental methods.

\section{Research Procedure}

The procedure of maggot processing is by using an oven. Fresh adult maggot is ovened at temperature of $60 \mathrm{C}$ for 18 hours then grinderred it into maggot flour. Meanwhile, maggot processing using sangrai method is done by roasting fresh maggot for 15 minutes at a temperature of approximately $100^{\circ} \mathrm{C}$.

\section{Data Collection Technique}

Chemical content analysis uses proximate analysis which consists of water content, rough protein, rough fat, and rough fiber.

\section{Water Content Analysis}

The principle of water content analysis is the process of evaporation of water from inserted material into a porcelain cup and then put it in an oven at $107^{\circ} \mathrm{C}$. Determination of water content is based on differences of sample weight (B) before (B1) and after drying (B2) (Elfiano et al., 2014). Then it is calculated by applying the following formula:

$$
\% \text { kadar air }=\frac{\mathrm{B} 1-\mathrm{B} 2}{\mathrm{~B}} \times 100 \%
$$

\section{The Analysis of Rough Protein Content}

Protein content principle is the process of liberating nitrogen from material protein uses sulfuric acid by heating. The determination of total nitrogen and protein content use microkjeldahl method (digestion, distillation and titration) (Udding et al., 2014). The formulation of calculating protein content is as follows:

$$
\begin{aligned}
& \% \mathrm{~N}=\frac{\text { mLHCL X NHCL X }(14,008)}{\text { mg Sampel }} \mathrm{X100 \%} \\
& \% \text { Protein = \% Factor konversi }(6,25)
\end{aligned}
$$

\section{Analysis of Rough Fat Content}

The analysis of fat content was carried out by taking a sample by weighed \pm 2 grams and put it into filter paper (B), then put it in a special flask for empty fat in an oven at $105^{\circ} \mathrm{C}$ for an hour. Then put the sample into exicator for \pm 20 minutes and weighed (A). Then the sample was wrapped in filter paper, put it into soxlet fat and added $\pm 30 \mathrm{ml}$ of acetone / ether, then put it up into extraction tool and extract it for 4 hours. Take the flask and oven it at $105^{\circ} \mathrm{C}$ for an hour. Cool the flask in the excicator and weigh (C) ((Hernaman et al., 2005)). The percentage of fat 
content can be calculated using the following formula.

$$
\% \text { lemak kasar }=\frac{\mathrm{C}(\mathrm{g})-(\mathrm{A})(\mathrm{g})}{\mathrm{B}(\mathrm{g})} \times 100 \%
$$

\section{Analysis of Rough Fiber Content}

The rest of the extracted sample (B) is then taken to the filter paper and oven at $105^{\circ}$ $\mathrm{C}$ for an hour, put in an excicator and weighed (A). The sample was put into a $250 \mathrm{ml}$ beaker glass, added $200 \mathrm{ml}$ of $\mathrm{H} 2 \mathrm{SO} 40.255 \mathrm{~N}$ and covered with plastic and tied it using a rubber band. Then put waterbath and count for an hour from starting to boil. Let it to be cool and filter it until the residue is left on the filter paper. Rinse the beaker glass. The residue is put intoa beaker glass and add $200 \mathrm{ml}$ of $\mathrm{NaOH} 0.313 \mathrm{~N}$, cover it with plastic and rubber bands, bring to a boil and filter it. Rinse the beaker glass again and oven at $105^{\circ} \mathrm{C}$ for an hour, put the excicator and weigh it (C) (Udding et al., 2014). Calculation / Formulas for Rough Fiber Content is as follow:

$$
\text { Kadar } \mathrm{SK}=\frac{(\mathrm{C}-\mathrm{A}) \mathrm{X} 100 \%}{\mathrm{~B}}=\mathrm{SK} \%
$$

Information :

$\mathrm{A}=$ weight of the empty filter paper

$\mathrm{B}=$ sample weight

$\mathrm{C}=$ frequent paper weight and residue after oven

\section{RESULT AND DISCUSSION}

The research results on the chemical quality of maggot flour uses sangrai method processing is as follows:

Table 1. Nutritional content of maggot (fresh and roasted)

\begin{tabular}{|l|c|c|}
\hline \multicolumn{1}{|c|}{ Contents } & $\begin{array}{c}\text { Fresh } \\
\text { maggot }\end{array}$ & $\begin{array}{c}\text { Sangrai } \\
\text { maggot }\end{array}$ \\
\hline Water content (\%) & 79,12 & 5,69 \\
\hline Rough protein (\%) & 28,11 & 28,73 \\
\hline Rough fat (\%) & 11,64 & 15,79 \\
\hline Rough fiber (\%) & 7,82 & 10,60 \\
\hline
\end{tabular}

The Quality of Moisture Content of The Maggot Flour by Using Sangria Method Processing

The moisture content of baked fresh maggot is $(79.12 \%)$ was higher than maggot processed by using sangria method $(5.69 \%)$ (Table 1.). One factor influences the evaporation of water content is heat. The temperature used in sangria method is higher than fresh and roasted maggot. The higher temperature used in the drying process impacts on decreasing water content caused by the evaporation process (Yuniarti et al., 2013).

\section{The Quality of Rough Protein Maggot Flour} by Using Sangria Processing Method

The protein content of maggot flour uses sangria processing is $(28.73 \%)$ was higher than baked fresh maggot $(28.11 \%)$. The results showed that oven-treated maggots contained of $50.9 \%$ rough protein (Aniebo \& Owen, 2010). In addition, the protein content of maggot flour has an amino acid profile, especially methionine and cystine, similar to soybean meal for the growth of broilers (Veldkamp \& Bosch, 2015).

\section{The Quality of Maggot Flour Rough Fat by Using Sangria Processing Method}

The rough fat content of maggot flour by using sangrai is $(15.79 \%)$ was higher than baked fresh maggot (11.64\%). The content of maggot rough fat is quite high. This is in accordance with the results of research which shows the rough fat content of maggot reaches 50\% (Rambet et al., 2015). Increasing the drying temperature causes a decrease in fat content. At high drying temperatures, there is a greater fat oxidation reaction (Yuniarti et al., 2013).

\section{The Quality of Rough Fiber Maggot Flour by Using Sangria Processing Method}

The rough fiber content of maggot flour by using sangrai is $(10.60 \%)$ was higher than rough fiber content of baked fresh maggot $(7.82 \%)$ (Table 1). This is probably due to the fact that it takes longer to process in the oven so that the fiber content gets increased. This is in accordance with the research which resulted in the rough fiber content of roasted maggot which was $6.2 \%$. The longer of roasting method produces higher 
rough fiber content. This is because the heat is given too long (Aniebo \& Owen, 2010). In addition, the higher the temperature used will increase the ash content. Increasing the ash content will increase the rough fiber content of a material (Yuniarti et al., 2013).

\section{CONCLUSION}

By making modifications to the development Sangrai method processing results lower air content $(5.69 \%)$ so that it is predicted to have a better storage capacity. The protein of maggot by sangrai method processing was higher $(28.73 \%)$, the rough fat content was higher $(15.79 \%)$, and the rough fiber content was higher $(10.60 \%)$ too.

\section{REFERENCES}

Aldi, M., Fathul, F., Tantalo, S., \& Erwanto. (2018). Pengaruh Berbagai Media Tumbuh terhadap Kandungan Air, Protein dan Lemak Maggot yang Dihasilkan sebagai Pakan. Jurnal Riset Dan Inovasi Peternakanvasi Peternakan, 2(2), 14-20.

Aldi, M., Fathul, F., Tantalo, S., \& Erwanto. (2018). Pengaruh Berbagai Media Tumbuh terhadap Kandungan Air, Protein dan Lemak Maggot yang Dihasilkan sebagai Pakan. Jurnal Riset Dan Inovasi Peternakanvasi Peternakan, 2(2), 14-20.

Aniebo, A. O., \& Owen, O. J. (2010). Effects of age and method of drying on the proximate composition of housefly larvae (Musca domestica Linnaeus) Meal (HFLM). Pakistan Journal of Nutrition, 9(5), 485487. pjn.2010.485.487

Azir, A., Harris, H., \& Haris, R. B. K. (2017). Produksi dan Kandungan Nutrisi Maggot (Chrysomya megacephala) Menggunakan Komposisi Media Kultur Berbeda. Jurnal Ilmu-Ilmu Perikanan Dan Budidaya Perairan, 12(1), 34-40.

Beski, S. S. M., Swick, R. A., \& Iji, P. A. (2015). Specialized protein products in broiler chicken nutrition: A review. In Animal Nutrition (Vol. 1, Issue 2, pp. 4753). KeAi Communications Co. https:// doi.org/10.1016/j.aninu.2015.05.005

Elfiano, E., Subekti, P., \& Sadil, A. (2014).
Analisa Proksimat dan Nilai Kalor pada Briket Bioarang Limbah Ampas Tebu dan Arang Kayu. Jurnal Aptek, 6(1), 57-64.

Gao, Z., Wang, W., Lu, X., Zhu, F., Liu, W., Wang, X., \& Lei, C. (2019). Bioconversion performance and life table of black soldier fly (Hermetia illucens) on fermented maize straw. Journal of Cleaner Production, 230, 974-980. https://doi.org/10.1016/ j.jclepro.2019.05.074

Gold, M., Tomberlin, J. K., Diener, S., Zurbrügg, C., \& Mathys, A. (2018). Decomposition of biowaste macronutrients, microbes, and chemicals in black soldier fly larval treatment: A review. Waste Management, 82, 302-318. https://doi.org/10.1016/ j.wasman.2018.10.022

Hernaman, I., Hidayat, R., \& Mansyur. (2005). Pengaruh Penggunaan Molases dalam Pembuatan Silase Campuran Ampas Tahu dan Pucuk Tebu Kering terhadap Nilai pH dan Komposisi Zat-Zat Makanannya. Jurnal Ilmu Ternak, 5(2), 94-99.

Kardana, D., Haetami, K., \& Subhan, U. (2012). Efektivitas Penambahan Tepung Manggot Dalam Pakan Komersil Terhadap Pertumbuhan Benih Ikan Bawal Air Tawar. Jurnal Perikanan Dan Kelautan, 3(4), 177184.

Katayane, F. A., Bagau, B., Wolayan, F. R., \& Imbar, M. R. (2014). Produksi dan Kandungan Protein Maggot (Hermetia illucens) dengan Menggunakan Media Tumbuh Berbeda. Journal Zootek, 34, $27-$ 36.

Rachmawati, D., \& Samidjan, I. (2013). Efektivitas Substitusi Tepung Ikan dengan tepung Maggot dalam Pakan Buatan terhadap Pertumbuhan dan kelulushidupan Ikan Patin. Jurnal Saintek Perikanan, 9(1), 62-67-67. https://doi.org/10.14710/ ijfst.9.1.62-67

Rambet, V., Umboh, J. F., Tulung, Y. L. R., \& Kowel, Y. H. S. (2015). Kecernaan Protein Dan Energi Ransum Broiler Yang Menggunakan Tepung Maggot (Hermetia Illucens) Sebagai Pengganti Tepung Ikan. Zootec, 35(2), 13. https://doi.org/10.35792/ zot.36.1.2016.9314

Suciati, R., Faruq, H., Biologi, J. P., \& Timur, J. (2017). EFEKTIFITAS MEDIA 
PERTUMBUHAN MAGGOTS Hermetia illucens ( Lalat Tentara Hitam ) SEBAGAI SOLUSI PEMANFAATAN SAMPAH. 2(1), $0-5$.

Udding, R., Nohong, B., \& Munir. (2014). Analisis kandungan protein kasar (PK) dan serat kasar kombinasi rumput gajah (Pannisetum purpureum) dan tumpi jagung yang terfermentasi. Jurnal Galung Tropika, 3(3), 201-207.

Veldkamp, T., \& Bosch, G. (2015). Insects: A protein-rich feed ingredient in pig and poultry diets. Animal Frontiers, 5(2), 4550. https://doi.org/10.2527/af.2015-0019

Wardhana, A. H. (2017). Black Soldier Fly (Hermetia illucens) as an Alternative Protein Source for Animal Feed. Indonesian Bulletin of Animal and Veterinary Sciences, 26(2), 069. https:// doi.org/10.14334/wartazoa.v26i2.1327

Yuniarti, D. W., Sulistyati, T. D., \& Suprayitno, E. (2013). Pengaruh Suhu Pengeringan Vakum terhadap Kualitas Serbuk Albumin Ikan Gabus (Ophiocephalus striatus). Jurnal Mahassiwa Teknologi Hasil Perikanan, 1(1), 1-9. 